\title{
No rastro do discurso: para pensar a comunicação
}

Rosana de Lima Soares

\section{Resumo:}

Este artigo se propõe tratar de algumas possíveis articulações entre o conceito de discurso - a partir de diferentes perspectivas teóricas - e o campo da comunicação em suas relações com as mídias. Ao pensar esse campo a partir de interfaces com o conceito de discurso, é como mediação que o concebemos. A palavra «mídias», adotada como definidora de vários fazeres comunicacionais contemporâneos, aponta para essa relação: «média, meio, ponto médio» - um lugar intermediário que aponta articulações entre termos distintos, especialmente fatos e relatos, estabelecendo uma imbricação entre produtores e receptores desses discursos que transforma os modos tradicionais de pensar as relações entre cada um e cada um dos outros.

\section{Palavras Chave:}

comunicação, discurso, linguagem, mídias, filosofia.

\begin{abstract}
:
This article proposes to deal with some possible articulations between the conception of discourse from different theoretical perspectives - and the communication area in their relation with the media. When we think about this study area from the interfaces with the concept of discourse, we conceive it as mediation. The word «media», used to define many contemporary communicational productions, indicates this relation: «media, medium, middle point» - an intermediate place that indicates the articulations between distinct terms, specially facts and reports, establishing imbrications between producers and receptors of these discourses that change the traditional ways of thinking the relations between each one and each others ones.
\end{abstract}

\section{Keywords:}

communication, discourse, language, media, philosophy.

Este artigo se propõe tratar de algumas possíveis articulações entre o conceito de discurso - a partir de diferentes perspectivas teóricas - e o campo da comunicação em suas relações com as mídias. Ao pensar esse campo a partir de interfaces com o conceito de discurso, é como mediação que o concebemos. A palavra «mídias», adotada como definidora de vários fazeres comunicacionais contemporâneos, aponta para essa relação: «média, meio, ponto médio» - um lugar intermediário que aponta articulações entre termos distintos, especialmente fatos e relatos, estabelecendo uma imbricação entre produtores e receptores desses discursos que transforma os modos tradicionais de pensar as relações entre cada um e cada um dos outros.

O conceito de discurso, tal como o concebemos, é modulado na esteira dessas transformações. O discurso refere-se ao ato mesmo da língua, configurando-se como o domínio em que as relações simbólicas são tomadas como instituintes do sujeito e das realidades que o situam. Antes do discurso, portanto, não há realidade. Em outras palavras, os discursos dados socialmente inserem o sujeito em uma ordem simbólica que o precede e o define, sendo ao mesmo tempo transformada por ele, pois quem diz "humano" diz, ao mesmo tempo, "falante", e quem diz "homem falante" diz, ao mesmo tempo, "homem social" (cf. Kristeva, 1974). 
Daí a importância em apontar as diversas perspectivas teóricas (filosofia, linguagem, sociologia, entre outras) empenhadas em definir o conceito de discurso, trajeto que nos propomos realizar neste artigo. Ao propor um deslocamento no modo de pensar a comunicação, partimos do pressuposto de que o domínio discursivo, entendido como articulador das relações simbólicas e, por isso, o lugar em que se fazem e desfazem os laços sociais, é o campo privilegiado para seu estudo.

Os discursos instituídos (vigentes) determinam as formas das realidades constituídas. Ou seja: tudo o que se apresenta no mundo é constituído pelo discurso. Este é nosso ponto de partida, solo comum em que fundamos o artigo. $\mathrm{O}$ discurso, instituidor de realidades, deixa em seu trajeto pegadas, marcas, vestígios, sinais: um rastro que tentamos agora seguir. Um relato se constitui enquanto relação, descrição, notícia. Damos notícia de algo, comunicamos - «narramos». Ao percorrer um trajeto, «corremos ou andamos por ele». Neste percurso, «discorremos» sobre algo, atravessamos fronteiras. Tratamos de um tema, expondo-o, analisando-o. Corremos não apenas por ele mas «ao redor dele». É no percurso dessa viagem que chegamos ao «discurso»:

Do latim «discursus». 1. Peça oratória proferida em público ou escrita como se tivesse de o ser. 2. Exposição metódica sobre certo assunto; arrazoado. 3. Oração, fala. 4. Lingüística. Qualquer manifestação concreta da língua (sinônimos, nessa acepção: fala e parole). 5. Antigo. Raciocínio, discernimento. 6. Familiar. Palavreado vão, e/ou ostentoso: nada de discurso, vá direto ao assunto. 7. Familiar. Fala longa e fastidiosa, de natureza geralmente moralizante: toda vez que chega tarde, o pai faz-lhe um discurso. 8. Literatura. Qualquer manifestação por meio da linguagem, em que há predomínio da função poética (Aurélio, 1986).

Do discurso como "exposição metódica" ao discurso como "fala fastidiosa", chegamos a uma outra definição: a de "discurso" (do latim «discursus») como deslocamento de um lugar para outro (cf. Blackburn, 1996). O discurso, assim concebido, pode ser pensado como um "correr ao redor", discorrer (do latim «discorrere»). Tão perdidos que estamos neste conceito, apenas «corremos» a seu redor. Daí uma primeira pista para tentarmos remontar as razões que nos fizeram escolher tratar deste conceito. Dessa forma, gostaríamos de passar do simples "correr ao redor" - um movimento à esmo, de nenhum lugar para lugar algum - para o deslocamento de um ponto a outro - que faz com que de fato cheguemos a algum destino, traçando um percurso.

Há muitas expressões relacionadas ao termo discurso tomadas como se fossem consensuais, comumente utilizadas quando se referem à comunicação: "estruturação discursiva", "campo discursivo", "organização e construção discursiva", "mecanismos e estratégias discursivas", "mediação", entre outras. Diversos trabalhos analisam discursos específicos - das mídias, da história, da Aids, racial, de gênero, mítico, jornalístico, publicitário, ético, filosófico, antropológico, sociológico -, mas poucos atentam para o fato de que o conceito de discurso possa não estar sendo tomado na mesma acepção em cada um deles.

Além disso, um aspecto para nós fundamental tem sido muitas vezes negligenciado: a articulação de uma diferenciação básica estabelecendo ao menos dois níveis do problema - o discurso «instituinte», os discursos «instituídos». Estes últimos, sabemos, podem ser definidos a partir de várias concepções, legitimando as pesquisas que sobre eles se desenvolvem. Como vemos na nona definição do "Dicionário de Semiótica" (1979), enquanto «instituído» o discurso pode ser tomado de várias formas, atestando o valor de tais investigações ainda que o conceito permaneça ambíguo:

Nessa nova acepção, o termo discurso continua apesar de tudo ambíguo. Um domínio semiótico pode ser denominado discurso (discurso literário ou filosófico, por exemplo) em razão de sua conotação social, relativa ao contexto cultural dado (um texto medieval sagrado é considerado por nós como literário, dirá J. Lotman), independente e anteriormente à sua análise sintáxica ou semântica. A tipologia dos discursos, suscetível de ser elaborada nessa perspectiva, será, então, conotativa, própria 
de uma área cultural geográfica e historicamente circunscrita, sem nenhuma relação com o estatuto semiótico desses discursos (Greimas e Courtés, 1979: 128).

Notemos que a maioria das pesquisas realizadas em comunicação assume a definição dos discursos instituídos sem, entretanto, atentar para o discurso instituinte, concepção na qual realidade e linguagem não se separam. É no jogo entre o discurso (ordenador) nos discursos (específicos) que buscamos investigar as origens do discurso e as diversas acepções em que este conceito vem sendo tomado ao longo da história do pensamento (em diferentes campos do conhecimento, principalmente a filosofia e a lingüística) para, finalmente, defini-lo com maior precisão em uma síntese teórica: o discurso como "laço social".

Na busca por delinear o "discurso nos discursos", remontamos às origens da palavra "discurso" no grego e no latim, e às definições de discurso em diferentes áreas do conhecimento (semiótica, comunicação, lingüística, sociologia, política, antropologia) para, ao final, priorizar o trajeto deste conceito ao longo da história da filosofia. Comecemos pelas grafias antigas de discurso, que remontam às línguas grega e latina. Em grego, discurso se diz «Lógos», termo freqüentemente a ele associado em textos filosóficos. Em latim, observamos a referência ao "correr por todos os lados e para diferentes lugares", já apontada anteriormente:

Etmologicamente, temos a seguinte definição: "Discursar/sivo/so - discorrer, vb. Percorrer, atravessar; tratar, expor, analisar. Do lat. discurrere, de currere. Discurso, XVI, do lat. discursus, de discursum, supino de discurrere" (Cunha, 1982). Notemos a idéia de movimento e dinamismo, que remonta ao «Lógos» grego, presente nessas definições.

Há inúmeros dicionários de filosofia que trazem definições do termo discurso, alguns de forma extensiva, remetendo à história desta disciplina. A título de ilustração, apresentamos algumas delas que, embora sucintas, são abrangentes no sentido de apontar as principais conceituações de discurso na filosofia. No "Oxford Dictionary of Philosophy" (1996), Simon Blackburn define discurso como sendo um fluxo contínuo de linguagem que contém mais do que uma sentença: conversações, narrativas, argumentos, declarações. Estende-se à concepção lingüística afirmando que a "análise do discurso" é a descrição lingüística e social das normas que governam tais produções, e pode incluir (na lingüística crítica, ou sociolingüística) ênfase sobre os determinantes sociais e políticos das formas tomadas pelo discurso, incluindo critério de credo, raça, gênero, classe social.

Andre Lalande, em "Vocabulaire Technique et Critique de la Philosophie" (1992), enumera a grafia do termo em diversas línguas: «discursus», em latim; «discourse» ou «speech», em inglês; «discorso», em italiano; «discours», em francês; «discurso», em espanhol; «rede», em alemão (interessante observar as noções contíguas, em português, de rede - enquanto entrelaçamento, trama - e discurso). Apresenta então duas conceituações para o termo: a) operação intelectual que se efetua a partir de operações elementares parciais e sucessivas; na filosofia, o discurso teria caráter geral, em oposição à intuição (no sentido kantiano), de caráter particular; b) expressão e desenvolvimento do pensamento por uma série de palavras ou de proposições que se encadeiam. É interessante notar nessa definição a palavra "encadeamento", que nos remete à idéia de "cadeia discursiva" e ao conceito de "cadeia significante" da linguagem (cf. Lacan, 1998), e novamente a "rede".

Ted Honderich, em “The Oxford Companion to Philosophy” (1995), realiza uma longa exposição sobre o termo discurso. Além da aproximação filosófica, inclui uma exposição a partir da lingüística. Começando por Benveniste, afirma que, de acordo com este autor, "discurso" é linguagem da forma mais extensiva que possa ser interpretada em referência ao emissor ("língua em ato"), em relação a sua localização espácio-temporal ou a outras variáveis que possam especificar o contexto a partir do qual se fala. Nesse sentido, "discurso" seria a linguagem posta em ação, a língua assumida pelo falante. Cabe aqui uma ressalva, a partir de um outro dicionário. No "Dicionário de Filologia e Gramática" (1968), J. Mattoso Câmara Junior afirma que, em 
relação à fala, o termo "discurso" é o que melhor corresponde ao termo francês «parole», estabelecido por Saussure (1922). Dessa forma, discurso seria a "mensagem" na base do "código" que é a língua.

Em Benveniste, o estudo do discurso inclui pronomes pessoais ("pessoa"), dêiticos de lugar ("espaço") e marcas temporais ("tempo"), na ausência dos quais o "ato de fala" em questão careceria de sentido. A "análise de discurso", por sua vez, operaria no nível supra-gramatical, em que as sentenças podem ser apresentadas em termos de pressuposições, implicações contextuais, coerência argumentativa, conhecimento do mundo e do orador, entre outros. Em seguida, Honderich apresenta uma definição mais genérica, afirmando que "discurso" significa também qualquer forma de linguagem mais longa ou mais complexa do que uma sentença individual, aproximando-se da definição de Blackburn, e passa a tratar especificamente da filosofia. Nesta área, afirma que o "discurso" interessa mais de perto ao campo da análise lógico-semântica e àqueles que operam com uma visão mais global das questões que surgem de qualquer teoria do sentido, considerando a possibilidade de uma "relatividade ontológica" ou a existência de um grande grau de variação em termos conceituais.

Em um livro abrangente, organizado por André Noiray, denominado "La Filosofia - las Ideas, las Obras, los Hombres" (1974), o autor afirma que atualmente a validade da intuição tem sido discutida tanto pelas ciências como pela filosofia. A oposição clássica entre o discursivo e o intuitivo deu lugar a outra, aquela entre ciência e ideologia: "A primeira constrói seu objeto organizando conceitos em um campo de validade determinado. A segunda permanece prisioneira das evidências do mundo vivido e das significações não fundadas (fundamentadas) que identificam a realidade mesma" (Noiray, 1974).

Mas a aproximação que nos interessa mais de perto se dá no final do verbete, quando Noiray refere-se às filosofias contemporâneas principalmente a partir de Derrida e Lacan, nos quais o termo "discurso" teria recuperado em parte seu sentido "oratório" (ora = boca, em latim), designando mais propriamente a palavra por oposição à escrita (escritura): "O discurso teria por função, segundo Lacan, dissimular ou excluir o objeto inconsciente do desejo; tal é o sentido de sua fórmula 'O discurso (o dizer, a palavra) é a subjetivação do sexo"”. O autor prossegue: "Assim, o discurso de consciência a consciência, pelo desvio de linguagem, não seria para si mesmo sua própria verdade, já que suas intenções remetem a certo sentido que está à margem, descentrado com relação ao julgamento consciente" (Noiray, 1974). Em tal definição, encontramos remetências às concepções de linguagem e de discurso propostas pela psicanálise freudiana, bem como ao conceito lacaniano de discurso como "laço social". Notemos que nessa concepção a verdade do discurso não se encontra nele mesmo, de consciência a consciência, mas remete a um sentido que se encontra à sua «margem», fora dele.

Para encerrar esta exposição, que poderia ainda se estender a inúmeros ramos do conhecimento, apresentamos uma síntese da minuciosa definição de "discurso" proposta no "Dicionário de Semiótica" (1979) para finalmente apresentar duas conceituações a partir das áreas de comunicação e das mídias. A definição de Greimas e Courtés, dividida em onze tópicos (já nos referimos anteriormente a um deles), aponta para o alcance deste termo em suas diferentes abordagens.

A primeira delas define discurso como "processo semiótico" e como "objeto do saber visado pela lingüística discursiva", sendo sinônimo de texto em seu sentido mais amplo (textos verbais ou não-verbais); a segunda, identifica discurso com "enunciado", considerando-o ou como resultado do encadeamento de frases, ou como um todo de significação no qual as frases são apenas segmentos; a terceira, trata de estabelecer modelos de "construção do discurso", ou seja, estabelece procedimentos e regras de análise indutiva a partir de seqüências consideradas como sucessões de frases-enunciados; a quarta abordagem, ao contrário da anterior, considera o enunciado-discurso como uma totalidade, procedendo sua análise pelo método dedutivo em vez de isolar suas partes componentes; a quinta abordagem envolve conceitos mais complexos, como os de "língua/fala", "sistema/processo", "competência/performance", buscando analisar as condições necessárias ao exercício da 
enunciação para além da simples construção de enunciados. Notamos aqui, em relação às quatro primeiras definições, um deslocamento que desprende o discurso do texto e passa a se preocupar com suas formas de construção, restringindo assim sua definição.

Vejamos as abordagens seguintes. A sexta abordagem continua o movimento anterior e apresenta a enunciação, segundo Benveniste, como a "colocação em discurso" da língua, estabelecendo um processo de discursivização de estruturas narrativas e enunciativas em estruturas discursivas. A sétima apresenta-se como desdobramento da sexta, apontando para o fato de que o discurso concebido a partir da enunciação anula a diferença entre discurso (monólogo entre frases) e comunicação (diálogo pela troca de frases). Esta última passa a ser uma das instâncias do discurso e não uma estrutura situada fora da língua e utilizada na troca de mensagens, de caráter apenas operacional ou social. Notamos aqui outro importante deslocamento, pois tal definição retira o caráter instrumental do discurso e, além disso, retira da comunicação as noções da pragmática e da cibernética (cf. Craig, 1999) referentes ao uso e ao domínio de regras para "bem comunicar", já que o discurso ultrapassa a própria ação dos sujeitos nele inscritos.

A oitava abordagem alerta para o fato do termo discurso ter passado, progressivamente, a ser identificado com "processo semiótico", afastando-se assim da lingüística. Tal identificação obriga a que se diferencie a semiótica enquanto sistema e enquanto processo (enquanto objeto de conhecimento e objeto construído pela descrição). A nona abordagem, já mencionada, remete ao conceito de discurso como "processo que pressupõe o sistema", em suas diferentes configurações. Podemos pensar aqui em uma distinção entre "discurso" e "discursos" ("o discurso nos discursos" de Donaldo Schüler), o que explicaria sua multiplicidade - já que cada "domínio semiótico" pode ser denominado discurso (literatura, filosofia, política, arte, sociologia etc.). Enquanto processos, os discursos estariam relacionados a contextos culturais dados, próprios de uma área cultural geográfica e historicamente circunscrita, sem nenhuma relação com seu estatuto semiótico (sistema), definindo-se a partir de critérios conotativos.

Na décima abordagem, Greimas e Courtés apontam o caráter ainda ambíguo em definir o que seja, de fato, discurso no sentido semiótico, especialmente nas relações estabelecidas entre formas e conteúdos dos discursos; alguns conteúdos podem ser assumidos por qualquer discurso (podem adquirir formas discursivas muito diversas), enquanto outros possuem organizações mais profundas e menos variáveis. Finalmente, a décima primeira abordagem resgata a questão da enunciação como lugar de geração do discurso para dizer que "a forma do discurso produzido depende da dupla seleção que é aí operada", entre os campos sintático e semântico. Ao destacar do repertório semântico as formas necessárias para «discorrer», as escolhas da enunciação determinam o tipo de discurso que será enfim manifestado. Por um processo de seleção e combinação das unidades disponíveis na língua, a enunciação produz um discurso que se coloca, sempre, "como uma seleção contínua dos possíveis, a qual abre caminho através das redes de coerções" (Greimas e Courtés, 1979: 125-130).

Ainda que concebendo o discurso a partir de um campo específico - e, dessa forma, possuidor de limites a ele inerentes -, é interessante observar que no traçado de suas conceituações os autores começam por apontar o discurso como sinônimo de texto (e, nesse sentido, operando apenas em um dos eixos da linguagem, o sintagmático) para, em seguida, desdobrarem a definição inicial em uma série de outras definições derivadas umas das outras até chegarem a tratar da instância da enunciação.

Note-se que nesse último nível já estamos mais próximos da concepção de discurso como instância produzida por seleção e por combinação de unidades lingüísticas, articulado portanto a partir dos dois eixos da linguagem (2). Note-se ainda que, antes de chegar a esta definição final, Greimas e Courtés apontam o discurso como: sinônimo de enunciado; dotado de procedimentos e normas para sua construção; um dispositivo articulado em diferentes níveis narrativos; resultado da competência do enunciador; língua em ato; articulações significantes; comunicação; conteúdos investidos na enunciação; discursos instituídos 
socialmente produzidos; tipologia conotativa; processos semióticos. A fim de montar um quadro geral a partir da semiótica discursiva, os autores constroem, portanto, uma «cartografia do discurso»: mais do que apontar para suas várias definições, apresentam as inter-relações entre elas e as diversas possibilidades de abertura que contemplam.

Ainda no rastro do discurso, vejamos agora as definições a partir da comunicação. Carlos Alberto Rabaça e Gustavo Guimarães Barbosa apresentam no "Dicionário de Comunicação" (1987) três definições para o termo "discurso": práticas expressivas, atividade lingüística, peça oratória. Vejamos cada uma delas:

1) Processo de atuação das práticas expressivas ou significativas correntes numa comunidade lingüística. Toda prática expressiva de linguagem que vise à produção e à circulação social do sentido. "É discurso tanto a linguagem comum, espontânea, comunicativa, quanto a prática complexa, trabalhada, delimitada, de um saber jurídico" (Muniz Sodré). Deste modo, o conceito de discurso ultrapassa o de língua, pois esta remete a um tipo de discurso, considerado (pela teoria lingüística) a partir da dupla articulação. Os gostos, as imagens, os rituais são discursos, na medida em que visem a produzir um efeito de significação. Pode-se falar, assim, no "discurso analógico das imagens", no "discurso institucional" etc.

2) É "a atividade lingüística nas múltiplas e infindáveis ocorrências da vida do indivíduo" (Câmara Jr.). Segundo J. Câmara Jr., discurso é "portanto, a língua atualizada num momento dado, por um dado indivíduo, quer como fala (discurso oral), quer como escrita (discurso escrito)".

3) Peça oratória. Composição oral ou escrita destinada a ser proferida em público (ou escrita como se tivesse esse objetivo) (Rabaça e Guimarães, 1987).

Ao contrário da definição anterior, James Watson e Anne Hill, em "A Dictionary of Communication and Media Studies" (1991), apresentam uma concepção baseada nos contextos específicos dos discursos - ou, se preferirmos, em seus universos semânticos. Os autores definem o termo como uma forma, modo ou gênero de uso da linguagem. Cada pessoa possuiria em seu repertório toda uma gama de discursos possíveis - a linguagem do amor, da autoridade, do esporte, da vida doméstica. No sentido midiático, as notícias podem ser tomadas como um exemplo de discurso, refletindo em seu estilo e forma de apresentação as referências sociais, econômicas, políticas e culturais dos enunciadores.

Para concluir esse trajeto, vejamos ainda o "Dicionário de Filosofia" (1971) de José Ferrater Mora. O autor apresenta uma longa exposição sobre o termo "discurso", excedendo os limites da filosofia. Para não nos estendermos demasiadamente, destacamos a divisão estabelecida pelo autor no referido verbete, apresentando em seguida um breve resumo de cada uma das partes: a) a noção de discurso («discursus») na filosofia grega e medieval, e parcialmente na filosofia moderna; b) a noção de discurso («oratio») na lógica aristotélicoescolástica; c) a noção de discurso na semiótica contemporânea.

No primeiro sentido, o discurso contrapõe-se à intuição (como já foi referido anteriormente), a partir de filósofos como Platão, Aristóteles, Plotino, Santo Tomás de Aquino e, modernamente, René Descartes, Emanuel Kant e Baruch Espinosa, entre outros. O autor ressalta que tal contraposição não equivale à exclusão de um termo em favor do outro, mas à consideração do processo discursivo como uma forma de pensamento apoiada no pensar intuitivo. A intuição forneceria o conteúdo da verdade; o discurso, a forma. Nenhum desses filósofos rejeitou no processo de conhecimento um desses aspectos em detrimento do outro; o que neles varia são os graus de importância atribuídos a um ou a outro lado. Nessa concepção, afirma Ferrater Mora, o «discursus» se refere à passagem («cursus») de um termo a outro (ou de uma proposição a outra) no processo de raciocínio, detendo-se ao se deparar com uma proposição considerada "evidente por si mesma". 
No segundo sentido, o autor retoma Aristóteles, afirmando que neste filósofo já se encontrava a definição de «discurso» como uma declaração verbal - um som vocal ou uma série de sons vocais, chamados pelos escolásticos de vox - que possui uma significação convencional em que cada uma das partes pode ter um significado isolado em termos de dicção, mas não de afirmação ou negação. Ao dizer uma palavra nos referimos a algo mas nada afirmamos ou negamos sobre sua existência. Dos sons vocais chegou-se à concepção de discurso como um conjunto de signos escritos, estabelecendo uma primeira divisão entre discurso oral e discurso escrito. Entretanto, nessa concepção nem toda combinação de vocábulos pode ser chamada "discurso". Os discursos devem ter caráter enunciativo e articularm-se a partir de conceitos ou termos de tal forma encadeados que exprimam «algo acerca de algo». A definição de discurso em Aristóteles aproxima-se da definição de proposição, desta se diferenciando por não se aplicar apenas à lógica.

Finalmente, na semiótica contemporânea o discurso é entendido como um "complexo de signos que podem ter diversos modos de significação e de propósitos", dividindo-se em vários tipos. Ogden e Richards realizaram uma detalhada exposição dos tipos de discurso na obra "The Meaning of Meaning" (1923), dividindo-os em "simbólicos" (ou referenciais) e "emotivos" (ou expressivos). Os primeiros comunicam referentes; os segundos, sentimentos e atitudes. Ainda que aparentemente simplista, essa divisão foi repetida com outros termos - por diversos autores (cf. Ferrater Mora, 1971). Morris também apresenta uma tipologia dos discursos, classificando-os em "informativos", "valorativos", "incitativos" e "sistêmicos".

Acompanhemos as definições:

O discurso é informativo quando se produzem os signos de tal forma que são causa de que alguém atue como se algo houvesse tido, tivesse ou fosse ter certas características. O discurso é valorativo quando se usam os signos de modo que causem um comportamento preferencial em alguém. $\mathrm{O}$ discurso é incitativo quando se produzem os signos de tal forma que sejam suscitados modos mais ou menos específicos de responder a algo. O discurso é sistêmico quando se produzem os signos para organizar uma conduta que outros signos tendem a provocar (Ferrater Mora, 1971: 473).

Segundo os modos de significar, os discursos podem ser "designativos", "apreciativos", "prescritivos" e "formativos": "Um designador é um signo que significa características ou propriedades-estímulos de objetosestímulos. Um apreciador é um signo que significa como se possuísse um status preferencial para a conduta. Um prescritor é um signo que significa a exigência de certas respostas-seqüências. Um formador é um signo que significa como algo é significado em uma combinação de signos complexos mediante os quais algo é significado de modo identificativo" (Ferrater Mora, 1971: 473).

A combinação dos quatro modos com os quatro usos dá lugar a dezesseis tipos de discurso, considerados como "tipos ideais" e, por isso, não necessariamente encontrados de forma pura. Reproduzimos a seguir a tabela proposta por Morris, conforme apresentada por Ferrater Mora:

\begin{tabular}{|l|l|l|l|l|}
\hline Modo / Uso & Informativo & Valorativo & Incitativo & Sistêmico \\
\hline Designativo & Científico & Fictivo & Legal & Cosmológico \\
\hline Apreciativo & Místico & Poético & Moral & Crítico \\
\hline Prescritivo & Tecnológico & Político & Religioso & Propagandístico \\
\hline Formativo & $\begin{array}{l}\text { Lógico- } \\
\text { matemático }\end{array}$ & Retórico & Gramático & Metafísico \\
\hline
\end{tabular}

Concluída nossa exposição, é interessante notar como a maioria das acepções de discurso apresentadas nos diferentes campos do conhecimento refere-se ainda à clássica divisão entre realidade e linguagem; além disso, todas pressupõem a ação de um sujeito racional, dotado de consciência, ou de um sujeito performativo por meio do discurso (notemos como exceção a referência a Derrida e Lacan em sua problematização da comunicação de "consciência a consciência", conforme apresentada por Noiray). 
Após esse "breve passeio pelos bosques do discurso", parodiando um belo título de Umberto Eco, priorizamos a definição do termo "discurso" a partir da filosofia não mais em sentido etimológico mas a partir de suas raízes gregas. Alertamos mais uma vez para o fato de que o termo "discurso" possui inúmeras definições e configurações na história da filosofia, como pudemos perceber na primeira parte deste artigo.

Principiamos nossa incursão nos gregos em busca do termo discurso enquanto «Lógos». O «Lógos»nos conduz aos primórdios da lógica e aos filósofos que sobre ela se debruçaram, sendo definido, pelos primeiros filósofos, como vida, razão e discurso, verdadeiramente uma questão de linguagem, e o sujeito se apresenta como aquele que «vive no discurso». Na filosofia, portanto, a palavra discurso está relacionada à noção grega de «Lógos» (linguagem-discurso, pensamento-conhecimento).

Estabelecendo uma estreita relação entre «Lógos» e linguagem, julgamos pertinente buscar as origens do discurso nos filósofos pré-socráticos. Entre eles, destacamos Heráclito de Éfeso e Parmênides de Eléia (ambos atingiram sua «akmé» (3) entre 504 e 500 a.C.). Preocupados com a origem, a transformação e o desaparecimento dos seres - o «devir»-, esses dois filósofos colocam-se em campos antagônicos. Heráclito concebia o ser como deslocamento, movimento, mudança, e Parmênides como permanência, imobilidade, imutabilidade.

Em Heráclito o mundo era visto como um "fluxo perpétuo"; para Parmênides, o que muda "não-é", o que "é" (existe) é aquilo que não muda. Em Heráclito, o «Lógos» é a mudança das coisas nos seus contrários; em Parmênides, é aquilo que permanece sempre imutável (o «ser», como pensamento e linguagem). Heráclito afirma que a impressão de que nada muda é apenas aparente (como as águas do rio), mas na verdade tudo está em permanente movimento e a «contradição» seria a lei racional da realidade. Parmênides afirma o contrário: que tudo parece estar em movimento, mas o que permanece é a identidade do ser imutável; a luta dos contrários é que seria mera aparência, e a lei racional da realidade é a «identidade». A filosofia grega desenvolve-se como a tentativa de encontrar uma solução para esta contradição (cf. Chauí, 1994).

Após Heráclito e Parmênides, portanto, a questão que se coloca para a filosofia é provar que a mudança e os contrários existem e podem ser pensados, mas que também existe a identidade e a permanência dos seres.

Platão e Aristóteles debruçaram-se sobre essa questão. Platão afirma que Heráclito tinha razão com relação ao mundo material ou físico, sujeito a mudanças e oposições (mundo natural ou sensível, das sensações, mas que é uma mera aparência). Quanto ao mundo verdadeiro ou ideal, Parmênides é quem estaria com a razão (mundo das essências imutáveis ou inteligível, sem contradições ou mudanças). A forma de se conhecer as essências ocorre por meio da dialética (“dupla lógica”): dois interlocutores possuem opiniões contrárias e devem chegar à mesma idéia sobre o que conversam, passando de imagens contraditórias a conceitos idênticos (cf. Chauí, 1994).

A dialética platônica é, portanto, um debate que separa algo em duas partes contraditórias para determinar qual dos contrários é verdadeiro e qual é falso, até que se chegue a um terceiro termo indivisível, que seria a idéia verdadeira ou essência daquilo que estivesse sendo investigado. A contradição está ligada às aparências, e a identidade às essências: "Superar os contraditórios e chegar ao que é sempre idêntico a si mesmo é a tarefa da discussão dialética, que revela o mundo sensível como heraclitiano (a luta dos contrários, a mudança incessante) e o mundo inteligível como parmenideano (a identidade perene de cada idéia consigo mesma)" (Chauí, 1994: 182).

Aristóteles, por sua vez, não separa realidade e aparência em dois mundos diferentes e não aceita que a mudança ou o devir seja mera aparência ilusória; alguns seres teriam como essência mudar, outros teriam essência imutável. Entretanto, ao contrário de Heráclito, a mudança não se realiza sob a forma da contradição. A mudança não se caracteriza como a transformação das coisas em seus opostos mas como a realização das potencialidades do ser, já contidas em sua essência (que não é contraditória, mas uma identidade que o 
pensamento pode conhecer). Para Aristóteles, a filosofia deve buscar conhecer como e porquê as coisas, sem mudarem sua essência, transformam-se, e porquê há seres imutáveis.

Nesse sentido, a dialética platônica não é segura para estabelecer conhecimento, pois parte de simples opiniões contrárias; escolher uma das opiniões não garante chegar à essência do que está sendo investigado. Essa dialética é boa apenas para a oratória e a retórica, nas quais cabe a persuasão, mas não para a demonstração ou a prova de uma verdade, localizadas no domínio da lógica (cf. Chauí, 1994). Se tomarmos a lógica seguindo a trilha de suas origens gregas, encontramos em Aristóteles seu grande idealizador, ainda sob o nome de "analítica". Na busca por estabelecer as relações entre a verdade, a realidade e a linguagem, a lógica aristotélica parte do pressuposto de que seria possível adequar os conceitos à realidade. Vale aqui uma incursão pela relação verdade-realidade em Aristóteles.

Ao tratarmos do «Lógos» referimo-nos a Parmênides e a identidade do ser, e a Heráclito e a mutabilidade do ser. Para o primeiro, só é aquilo que é idêntico a si mesmo, confrontando o mundo da mera opinião, a «Dóxa», aquilo que pode variar, ao mundo da verdade, nesse momento ainda definida como «Alethéia». Em Aristóteles, a lógica é o instrumento para o pensamento verdadeiro a partir de argumentos válidos, um "instrumento para a ciência" (não é conhecimento teórico ou prático sobre nenhum ser ou objeto). Nesse sentido, a «verdade» seria a correspondência entre a predicação feita pelo pensamento e as coisas - a adequação do conceito à realidade -, ou seja, a correspondência entre as palavras e as coisas não da forma como viria a ser tratada a partir da moderna noção de signo.

A partir da teoria aristotélica dos silogismos, a lógica se torna o instrumento para o pensamento verdadeiro. A «verdade» é definida como a correspondência entre a predicação feita pelo pensamento (no juízo, na definição e no silogismo) e as coisas (o mundo). O pensamento é verdadeiro quando afirma (reúne predicados num sujeito) ou nega (separa predicados de um sujeito) aquilo que, nas próprias coisas, já está unido ou separado. A verdade como «Alethéia» tem por seu oposto o «esquecimento», e não a mentira ou a falsidade. Define-se como "aquilo que não foi esquecido; o que é recordado"; aquilo que é encontrado, lembrado; como se fosse possível «ver» a realidade (ter a ela acesso direto), e não representá-la: note-se que nesse momento não havia ainda se instaurado, na concepção de verdade, a cisão entre o «olhar» e a «palavra» (o discurso) (cf. Chaú, 1988). Tal definição vai perdendo sua força desde Platão (até Aristóteles) e a verdade vai se tornando «orthótes», isto é, correção ou adequação do conceito à realidade («orthós» em grego quer dizer "correto"). «Adequar» o conceito à realidade é diferente de «ver» a realidade.

Ainda em relação à palavra "verdade", lembramos que a idéia ocidental deste termo (como oposta à mentira) foi formada a partir de duas outras palavras além da «Alethéia» dos gregos: a palavra latina «Veritas» (que se refere à veracidade de um relato) e a palavra hebraica «Emunah» (que significa confiança numa palavra divina).

«Alethés», o verdadeiro, significa o não-esquecido, o não-escondido; veraz, sincero, justo, eqüitável, verídico, franco, não-dissimulado. A «Alethéia» relaciona-se, assim, muito mais à mitologia grega, ao tempo dos oráculos e do destino. Com a filosofia ocidental e sua progressiva tentativa de racionalizar o mundo, a «verdade» vai perdendo esse sentido e, tomada pela ciência moderna, passa a corresponder a um mundo préexistente aguardando que suas leis possam ser enfim desvendadas. Pensada a partir da linguagem e de seus jogos, a verdade recupera na filosofia seu sentido original de algo que não está escondido, ou que apareceria quando «lembrado» pelas construções narrativas. Em relação às mídias, o tema da verdade como «Alethéia»e como «Orthótes» parece extremamente atual. Nesse sentido, resgatamos uma reflexão quanto ao imbricamento de elementos de ficção e de ciência (cf. Quéré, 1982) em seu «artefazimento».

A ficção («fictionis») presente no fazer midiático está sendo aqui tomada não no sentido de mentira mas de «fabricação e criação», enquanto «Alethéia» - lembrança - e, portanto, trazendo em si a impossibilidade de 
escapar de seu lado testemunhal, ou seja, profundamente comprometida e imbricada com aquele que fala (sujeito este que, desde Freud, sabemos ser dividido e não falar a partir de si mesmo). Os relatos midiáticos são, acima de tudo, narrativas construídas pelos falantes de uma língua. Se o acontecimento é sempre o "acontecido e desaparecido" (cf. Clément, 1973), se começa a escapar no momento mesmo de sua ocorrência, o relato sobre ele será sempre impreciso e fugidio, precário.

Da mesma forma, pensamos em «ciência» não no sentido de rigor dedutivo ou raciocínio lógico mas enquanto atividade que busca dotar seus relatos de uma certa precisão e objetividade (aquela possível a um sujeito que é, sobretudo, testemunha de uma falta, o que faz com que qualquer comunicação seja sobretudo um testemunho, ainda que malogrado). Por seu caráter de ciência, as mídias utilizam recursos como datas, dados, estatísticas, gráficos, para tornar algumas asserções (afirmativas ou negativas) incontestáveis - verdadeiros axiomas e postulados - na tentativa de garantir a credibilidade e a veracidade de seu relato. Poucas vezes notamos, por exemplo, títulos com asserções negativas ou condicionais nas manchetes dos jornais impressos. A «Alethéia» dos pré-socráticos contemplava a ficção, Aristóteles buscava a ciência da «Orthótes». Arriscaríamos dizer que é nesse imbricamento que se localiza o próprio fazer midiático.

Ainda em relação às mídias, vale lembrar uma cena vista recentemente nos cinemas, que evoca a antiga oposição alethéia x esquecimento. Embora trate de temas variados - entre eles a oposição entre realidade e irrealidade (ou simulacro) - gostaríamos de destacar do filme "Matrix" (1999) uma passagem que consideramos emblemática: vivendo em um mundo concebido no filme como não-real (leia-se nãoverdadeiro), em certo momento ao personagem principal é oferecida uma escolha: entre duas pílulas, uma vermelha e outra azul, deve tomar uma decisão (tomando as pílulas) entre «conhecer a verdade» (ter acesso e ver um mundo - no filme, o "real" - para ele ainda desconhecido) ou «cair no esquecimento» (voltar para sua "irrealidade cotidiana" - para usar uma expressão de Eco - esquecendo inclusive que a ele foi dada essa opção). Não nos interessa aqui a narrativa do filme, nem mesmo o que nele é caracterizado como "verdade" ou "esquecimento", como uma vida "real" (verdadeira) ou uma vida "irreal" (fingida), mas a inusitada escolha que se apresenta entre a verdade e o esquecimento, como na antiga «Alethéia» grega.

Retomamos o discurso em suas origens - o «Lógos» - e destacamos filósofos contemporâneos como Foucault, Deleuze, Lyotard e Derrida, entre outros, sabendo que nessas escolhas deixamos de contemplar uma série de filósofos importantes, conseqüência do fato de termos de privilegiar alguns em detrimento de outros. Dentre eles, fazemos agora uma incursão pelos sofistas e por Descartes, já que os primeiros, cabe lembrar, não podem ser negligenciados quando tratamos das questões da linguagem e do discurso.

Dos sofistas recuperamos a idéia de que um discurso é sempre a retomada de um outro discurso - um discurso só é possível a partir de outro - destacando, principalmente, Górgias, Protágoras e Isócrates. Note-se que de Protágoras e Górgias restaram apenas fragmentos, em sua maioria compilados por outros filósofos; de Isócrates, porém, há mais fontes primárias e secundárias. É nesse momento que convocamos Platão, especialmente em seus diálogos "Fedro", "Crátilo" e "O banquete", além de "Górgias" e "Protágoras". Apesar de tratar do tema da linguagem também nos diálogos "Eutídemo", "Teeteto" e "Sofista", é em "Crátilo" que Platão toma a linguagem como verdadeiro objeto de debate e não como tema para tratar de seu conceito de ontologia: "El 'Crátilo' no es el único diálogo platónico que trata el problema del lenguaje, pero sí es el único que trata el lenguaje como problema” (Calonge Ruiz et. al., 1987: 349).

Nesse diálogo, portanto, a linguagem não é tomada em sua estrutura e funcionamento específico mas questionada em sua possibilidade de ser um caminho que leve ao conhecimento: 'El 'Crátilo' no es un estudio del lenguaje en su estructura e funcionamiento. Es un debate sobre la validez del mismo para llegar al conocimiento. Tampoco hay que buscar en él, por consiguiente, una indagación sobre el origen, como se ha hecho a veces. Desde el principio mismo del diálogo, queda suficientemente claro que el verdadero tema es la «orthótes» ('rectitud' o 'exactitud') del nombre” (Calonge Ruiz et. al., 1987: 350); não a "correta" aplicação 
dos nomes mas a "adequação da linguagem à realidade".

O diálogo "Crátilo" tem início com um convite de Hermógenes para que Sócrates participe de sua discussão com Crátilo sobre a precisão e a exatidão das palavras ("nomes"): "Sócrates, aquí Crátilo afirma que cada uno de los seres tiene el nombre exacto por naturaleza. No que sea este él nombre que imponen algunos llegando a un acuerdo para nombrar y asignándole una fracción de su propia lengua, sino que todos los hombres, tanto griegos como bárbaros, tienen la misma exactitud en sus nombres” (Platão/“Crátilo”, 1987: 364). Enquanto Crátilo afirma que os nomes são exatos por natureza, Hermógenes pensa que sua precisão não passa de um pacto, de uma convenção, de um hábito. A discussão se desenvolve, então, em torno da oposição naturalismo/convencionalismo. Para o primeiro, a linguagem seria uma arte imitativa, e os nomes imitariam a essência das coisas por meio de letras e sílabas; para o segundo, a linguagem seria uma convenção, e os nomes não corresponderiam à realidade mas são atribuídos às coisas pelos homens.

Em torno dessa discussão, subjaz uma outra: a discordância de Platão quanto a alguns dos preceitos dos sofistas. Apesar de ter escrito sobre os sofistas e compilado alguns de seus fragmentos, Platão opõe-se ao conceito de discurso como retomada de outro discurso. Para Platão, há uma verdade já determinada e que pode ser alcançada, o que conduz ao conceito de discurso como algo existente em si mesmo, organizado em torno de uma razão. No caminho até os contemporâneos, a idéia de razão nos conduz a René Descartes e ao "Discurso do método" (1637), obra pioneira na utilização do termo "discurso" em títulos de tratados filosóficos. Afinal, se a filosofia é um discurso isso deve supor que existam «outros discursos» (ainda que enganadores), relativizando uma importância até então inquestionável.

Descartes hesitou em publicar um livro com o título de "discurso do método", pois ao fazê-lo estabelece a separação entre o saber e a verdade (ou entre a filosofia e a verdade) (4), rompendo com os preceitos platônicos e, em conseqüência, reformula a problemática da ciência moderna. Descartes também coloca-se como marco porque depois dele a assunção do termo "discurso" em obras de filosofia já estará sendo entrecortada pela lingüística, assumindo outras acepções.

$\mathrm{Na}$ tentativa de desenvolver um método (baseado em procedimentos matemáticos) "para bem encaminhar a razão e procurar a verdade nas ciências", Descartes descreve seu trajeto intelectual e estabelece que a formação do homem deve seguir uma ordem: formar em primeiro lugar uma moral, depois um senso de justiça e, finalmente, dedicar-se à filosofia - o estudo da sabedoria - para alcançar um "perfeito conhecimento de todas as coisas que o homem pode saber, tanto para a conduta de sua vida como para a conservação de sua saúde e a invenção de todas as artes" (Descartes, 1987: 7). Descartes está preocupado em apontar que, em todas as coisas, os efeitos dependem das causas e busca, dessa forma, estabelecer um método rigoroso: "Gostaria muito de prosseguir e de mostrar aqui toda a cadeia de outras verdades que deduzi dessa primeira" (Descartes, 1987: 51). O discurso é, então, fortemente associado à lógica aristotélica («Lógos») em seu sentido dedutivo de encadeamento de raciocínios para extrair de uma verdade outras que lhe seguem.

Seja nos sofistas ou em Descartes, o trajeto pela filosofia nos auxilia na compreensão de um dos aspectos do conceito de discurso a partir de Lacan: para falar, o sujeito deve retomar outro discurso já existente. O percurso ensaiado pela filosofia vem em auxílio dessa interrogação e da própria configuração do discurso enquanto sistema - estruturante e estruturado - dos sistemas simbólicos constituintes das relações sociais.

Do «Lógos» dos gregos e de seus desdobramentos, Lyotard nos auxilia a pensar o lógos contemporâneo, para ele inseparável da «Téchne»: o «tecnologos», a tecnologia, a telegrafia. Tomamos a pergunta central de Lyotard em um dos capítulos de "O inumano" (1988): "Será a passagem possível com ou permitida pelo novo modo de inscrição e de memoriação que caracteriza as novas tecnologias? Não irão estas impor as sínteses e as sínteses concebidas, de uma maneira ainda mais íntima nas almas do que qualquer tecnologia anterior? Mas por isso mesmo, não irão elas ajudar também a afinação da nossa resistência anamnésica?” (Lyotard, 
1990: 64).

As colocações de Lyotard nos possibilitam definir o «Lógos» contemporâneo como uma nova forma de inscrição tecnológica, vislumbrando alguns de seus possíveis efeitos em relação às mídias. $\mathrm{O}$ discurso da ciência - hoje tecnociência - que parece articular as relações contemporâneas remonta, em suas formas de inscrição e relação com a memória, à escrita conforme retomada por Derrida no livro "A farmácia de Platão" (1972): trata-se de formas de inscrição que realizam, ao mesmo tempo, um processo de cura e de exacerbação dos sintomas, colocando-se como remédio e veneno para a memória que tentam nomear. Os discursos instituídos pelas mídias (recorrentes em seus sentidos) tornam-se, assim, discursos instituintes de realidades sociais outras (divergentes em seus sentidos).

O caráter de «meidação» pressuposto nos discursos refere-se a seu aspecto de «construção do mundo», apontando para a indissociabilidade entre o campo discursivo e o campo social. Entre fatos e relatos, os acontecimentos só passam a ser reconhecidos como realidade por meio de construções narrativas operadas na linguagem, tornando-se «realidades discursivas». Nessa construção, pela própria definição de linguagem, algo sempre vai faltar - uma parte impossível de ser simbolizada. Se, por um lado, podemos afirmar não ser possível à linguagem recobrir integralmente um suposto mundo que a antecede, devemos afirmar, por outro, não ser possível à realidade constituir-se enquanto tal a não ser no incessante jogo de proximidade e distanciamento em relação à linguagem, por meio de formações e práticas discursivas.

\section{Bibliografia:}

BENVENISTE, E. Problemas de lingüística geral II. Campinas: Pontes, 1980.

BLACKBURN, S. The Oxford Dictionary of Philosophy. Oxford University Press: Oxford, 1996.

CALONGE RUIZ, J.; ACOSTA MÉNDEZ, E.; OlIVIERI, F. J.; CALVO, J. L. Diálogos. Gorgias, Menéxeno, Eutídemo, Menón e Crátilo. Vol. II. Traduções, introduções e notas. Madri: Gredos, 1987 (col. Biblioteca Clássica Gredos).

CÂMARA JUNIOR, J. M. Dicionário de Filologia e Gramática. Rio de Janeiro: J. Ozon, 1968.

CHAUÍ, M. “Janela da alma, espelho do mundo". In: NOVAES, A. (org.). O olhar. São Paulo: Companhia das Letras, 1988. Convite à Filosofia. São Paulo: Ática, 1994.

CLÉMENT, C. B. “Continuidade mítica e construção histórica”. Le pouvoir des mots. Symbolique et idéologique. Paris: Maison Mame, 1973 (mimeo.).

CRAIG, R. T. “A comunicação na conversação de disciplinas”. Comunicações e Artes, ECA/USP, n. 28, jan./abr. 1994.

. Communication theory as a field. Part I. Congresso Anual da Associação Internacional de Comunicação (ICA), Montreal, Canadá, maio de 1997.

. "Communication theory as a field. Part II". Communication Theory. International Communication 
Association, vol. 9, n. 2, maio de 1999.

CUNHA, A. G. da. Dicionário Etimológico da Língua Portuguesa. Rio de Janeiro: Nova Fronteira, 1982.

DERRIDA, J. A farmácia de Platão. $2^{a}$ ed. São Paulo: Iluminuras, 1997 (Biblioteca Pólen).

DESCARTES, R. “Discurso do método”. Os Pensadores. São Paulo: Nova Cultural, 1987.

FERRATER MORA, J. Dicionário de Filosofia. Tomo I (A-K). Buenos Aires: Sudamericana, 1971.

GREIMAS, A. J. \& COURTÉS, J. Dicionário de Semiótica. São Paulo: Cultrix, 1979.

HOLANDA FERREIRA, A. B. de. Novo Dicionário Aurélio da Língua Portuguesa. $2^{\mathrm{a}}$ ed. Rio de Janeiro: Nova Fronteira, 1986.

HONDERICH, T. (ed.). The Oxford Companion to Philosophy. Oxford University Press: Oxford, 1995.

KRISTEVA, J. História da linguagem. Lisboa: Edições 70, 1974 (col. Signos).

LACAN, J. Escritos. Rio de Janeiro: Jorge Zahar, 1998 (col. Campo Freudiano no Brasil).

LALANDE, A. Vocabulaire Technique et Critique de la Philosophie. Vol. 1. Paris: Quadrige/PUF, 1992.

LEMAIRE, A. “Os dois grandes eixos da linguagem”. Jacques Lacan, uma introdução. 4 ' ed. Rio de Janeiro: Campos, 1989.

LYOTARD, J.-F. A condição pós-moderna. $2^{\mathrm{a}}$. ed. Lisboa: Gradiva, 1989 (col. Trajectos).

LYOTARD, J.-F. O inumano: considerações sobre o tempo. Lisboa: Estampa, 1990 (col. Margens).

NOIRAY, A. (org.). La Filosofia - las Ideas, las Obras, los Hombres. Bilbao: Mensajero, 1974.

PLATÃO. “Crátilo”. In: Diálogos. Gorgias, Menéxeno, Eutídemo, Menón e Crátilo. Vol. II. Madri: Gredos, 1987 (col. Biblioteca Clássica Gredos).

QUÉRÉ, L. Des miroirs equivoques. Paris: A.-M., 1982.

RABAÇA, C. A. \& BARBOSA, G. G. Dicionário de Comunicação. São Paulo: Ática, 1987.

SAUSSURE, F. Curso de lingüística geral. São Paulo: Cultrix, 1970.

WATSON, J. \& HILL, A. A Dictionary of Communication and Media Studies. $2^{\mathrm{a}}$ ed. London: Hodder \& Stoughton, 1991.

\section{Notas:}

(1) Doutora em Comunicação, é professora da ECA-USP, atuando nas áreas de jornalismo, linguagem e mídias. Pesquisadora do Grupo de Estudos de Linguagem: Práticas Midiáticas, é autora de "Imagens veladas: aids, imprensa e linguagem" (Annablume, 2001).

(2) Apenas a título de recordação, retomamos aqui a divisão dos "dois eixos da linguagem" a partir de Jakobson, conforme apresentada por Lemaire (1989). A linguagem opera a partir de dois eixos paradigmático e sintagmático, que podem ser visualmente representados em um gráfico de coordenadas $\mathrm{x}$ (vertical) e y (horizontal). 
(3) As datas de nascimento e morte de Heráclito e Parmênides são obscuras. A fim de estabelecer uma referência temporal mínima, optamos por apontar a época de sua «akmé», ou "maturidade intelectual".

(4) Notemos que para atingir a verdade a filosofia coloca-se como um «método» específico para "bem conduzir” a razão (atingindo o saber), ou seja, a própria razão pode enganar-se, mentir, iludir-se.

\section{Mini Currículo :}

Doutora em Comunicação, é professora da ECA-USP, atuando nas áreas de jornalismo, linguagem e mídias. Pesquisadora do Grupo de Estudos de Linguagem: Práticas Midiáticas, é autora de "Imagens veladas: aids, imprensa e linguagem" (Annablume, 2001). 